\title{
Research Abstracts
}

\author{
Khaled Abou El Fadl
}

خالد أبو الفضل: القرآنوالأخلاق والفقه الإسلامي

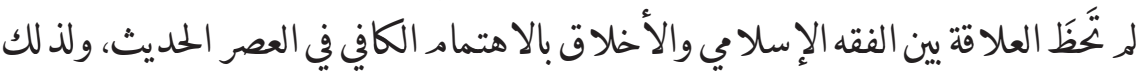

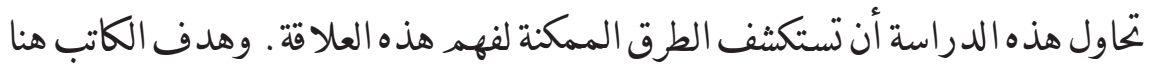

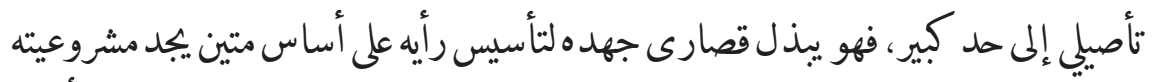

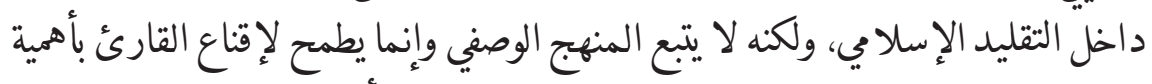

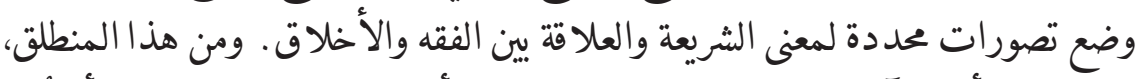

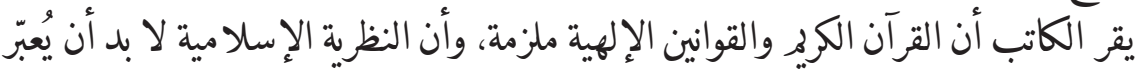

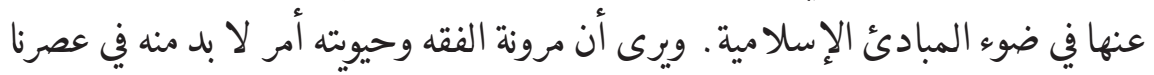

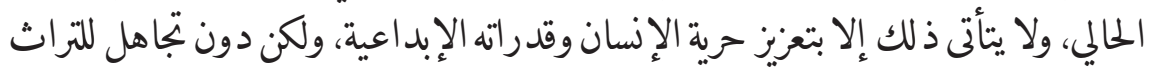
الفقهي الإسلامي. فالراث الفقهي له دور برهاني وتوجيهي مهم، فكا بيّن الإدئ العديد من

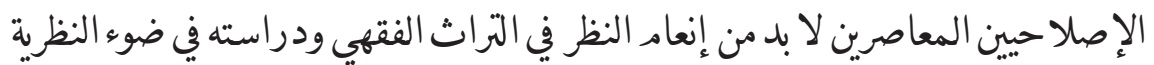

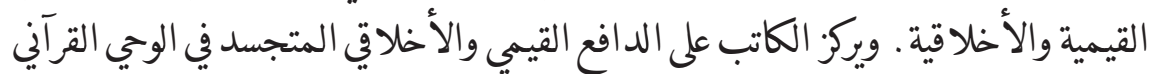
وقدرته على تطوير الآراء الفقهية في العصر الحالي.

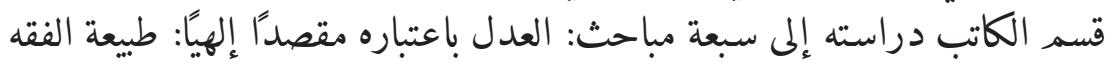

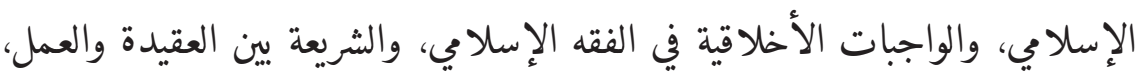

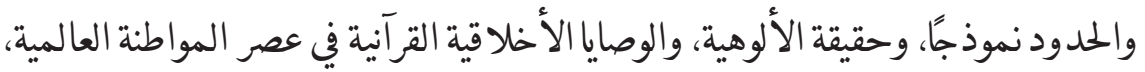

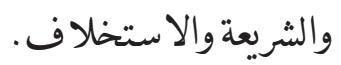

وفي الحتام تقرر الدراسة أن الأحكام التي استنبطها الفقهاء السابقون لا يمكن اعتبارها

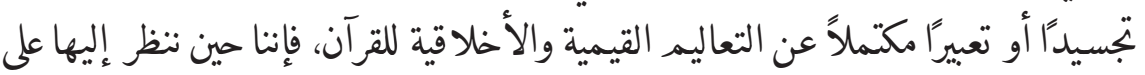

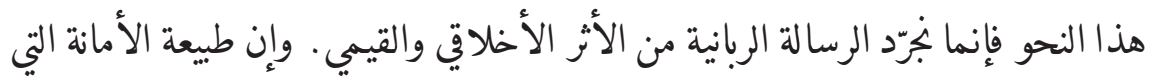

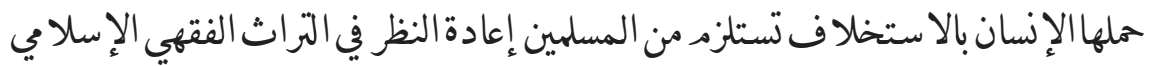

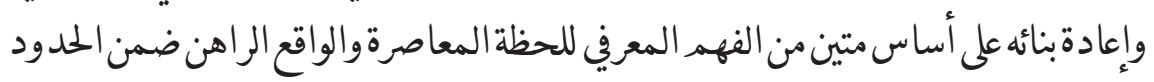

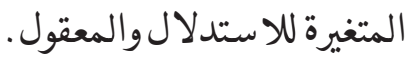




\section{Khaled Abou El Fadl, Éthique coranique et droit islamique}

La question du droit et de la morale islamiques n'a pas été suffisamment étudiée à l'époque moderne. C'est pourquoi cet essai se présente comme un effort d'exploration de manières possibles de comprendre la relation existant entre, d'une part, l'éthique et, d'autre part, la charia et la loi islamique.

L'auteur soutient qu'à l'époque contemporaine le dynamisme et la vitalité de la loi islamique doivent être préservés et qu'un tel résultat ne peut être atteint sans le maintien de la liberté et des capacités d'innovation propres à l'individu. En outre, il ne croit pas au caractère opportun ou raisonnable d'ignorer ou de rejeter tout le patrimoine juridique islamique. Au demeurant, il serait intellectuellement irresponsable et pédagogiquement incohérent de le faire. À son avis, le patrimoine juridique islamique joue non seulement un rôle instructif et démonstratif important, mais sert également de point d'ancrage essentiel pour les musulmans contemporains. Sous cet angle, la question sur laquelle il centre l'intérêt dans cet essai est l'impulsion éthique et morale contenue dans la révélation coranique et sa capacité normative à transformer les modes d'articulation de la loi islamique à l'époque moderne.

L'auteur a divisé son papier de recherche en sept paragraphes, à savoir : "la justice comme voie de la divinité: la nature de la jurisprudence islamique", "les engagements éthiques dans la loi islamique", "la charia comme idéologie et pratique," "l'exemple des ḥudūd, peines légales prescrites par le Coran et la tradition prophétique"," la poursuite du caractère véridique de la divinité," "les impératifs coraniques éthiques à l'ère du cosmopolitisme", et "la charia et le califat comme modèle de dévotion et de piété".

Lauteur conclut que les jugements ou les lois déduites par les premières générations de juristes ne peuvent pas être considérées comme l'incarnation ou comme la pleine articulation des enseignements coraniques d'ordre moraux et éthiques. De par la nature même de la confiance divine faite aux hommes en tant que vicaires sur terre, les musulmans sont tenus de revoir et de réélaborer la tradition juridique islamique sur la base des compréhensions épistémologiques propres à l'époque contemporaine et dans les limites raisonnables des changements survenant sans cesse au sein du monde.

\section{Mariam Al-Attar}

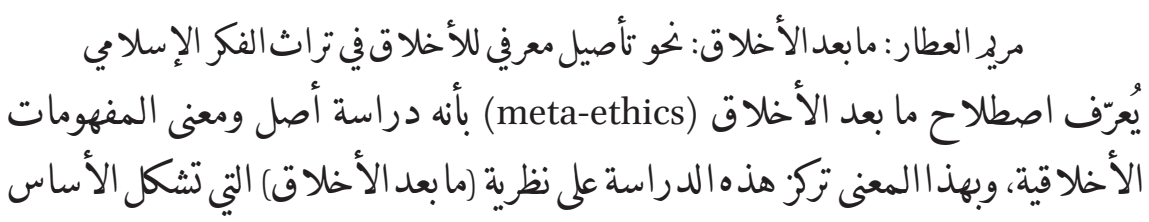


المعريف لنظرية مقاصد الشريعة. تقترح الدراسة إعادة النظر في الأساس الميتا أخلاقي

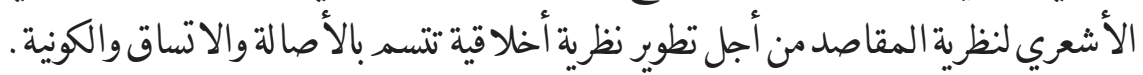

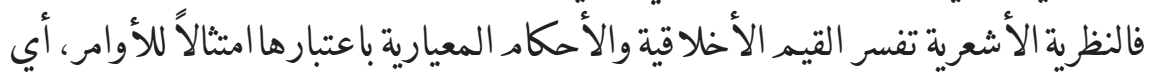

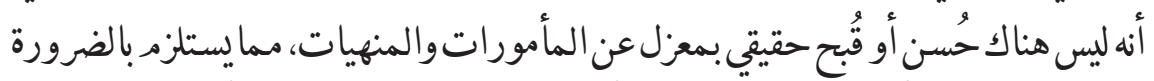

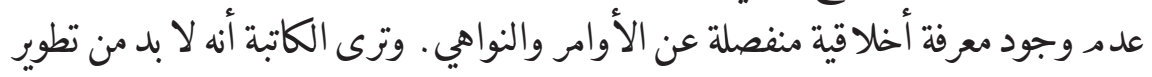
نظرية المقاصد بحيث نلغني التعارض بينها وبين نظرية التكليف العقلي التي طرحها المعتزلة

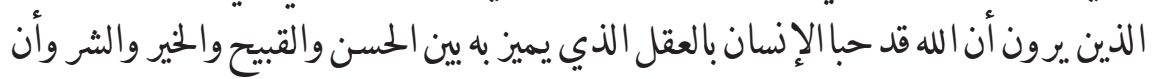

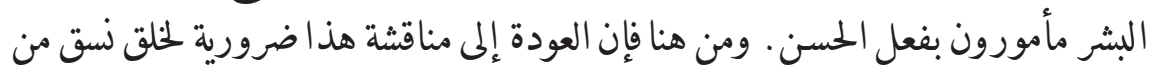

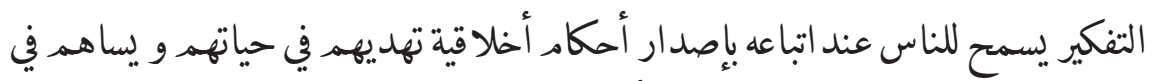

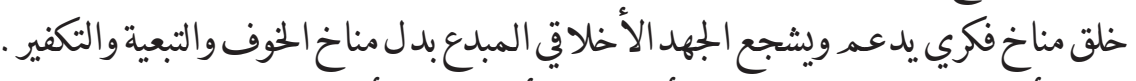

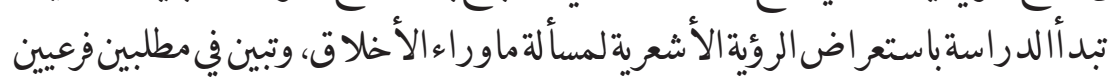

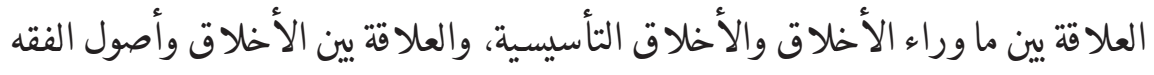

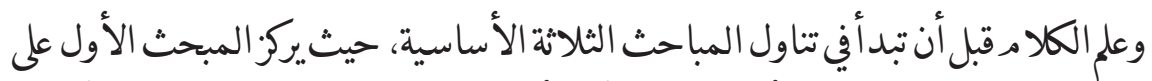

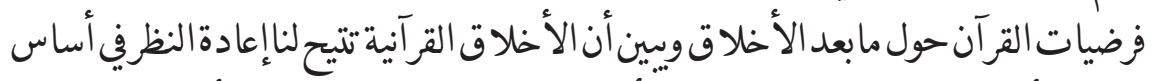

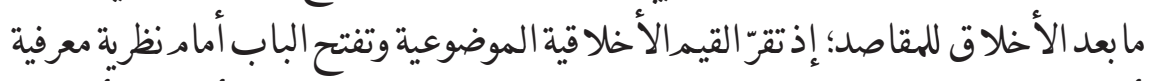

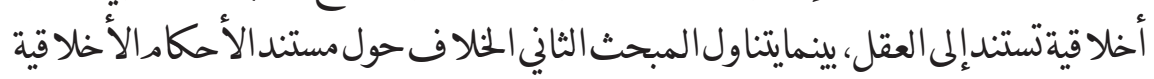

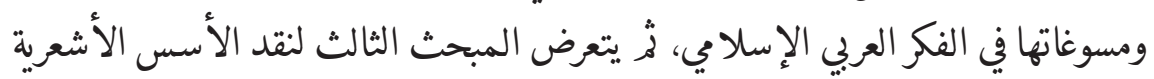

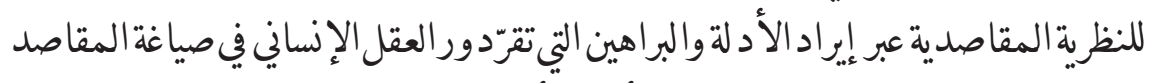

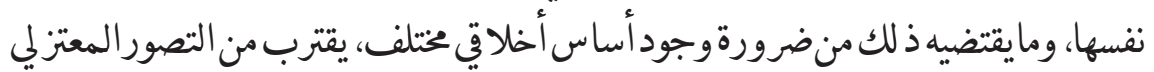

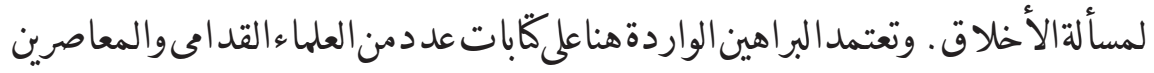
الذين لا حظوا التناقض في نظرية المقاصد التقليدية، علاوة على آراء بعض العلماء الذين صرّحوا

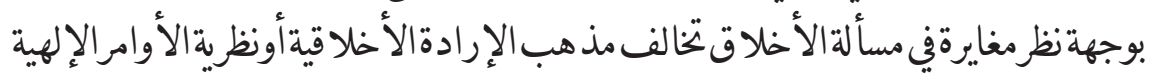
في تناول قضية الأخلاق.

\section{Mariam Al-Attar, La méta-éthique: recherche d'une base} épistémologique de la morale dans la pensée islamique classique

Le but visé par cet article consiste à évaluer de manière détaillée et analytique le fondement méta-éthique de la théorie connue sous le nom de maqāṣid al-sharīa a, généralement traduite par "les buts ou les objectifs de la 
loi islamique." La théorie des maqāṣid est ici clairement présumée être normative plutôt que simplement descriptive. Pour la présente recherche, repenser le fondement méta-éthique servant de base épistémique à la théorie des maqāṣid demeure essentiel pour développer une théorie morale plus cohérente et bien fondée. Par conséquent, cet article soutient que maqāșid al-sharī'a, en tant que théorie morale normative, devrait être amendée et conciliée avec la théorie de "l'obligation rationnelle" (al-taklîf al-'aqlī).

La théorie qui a d'habitude fourni le fondement méta-éthique de la théorie normative est la théorie ash'arite du bon et du mauvais (husn wa-qubh), qui est analogue à la "théorie du commandement divin." Cette théorie affirme que les valeurs morales (portant sur le bien et le mal) n'ont absolument aucun sens en dehors des commandements et interdictions divins. En revanche, la théorie de "l'obligation rationnelle," élaborée par les Mu'tazilites, implique que tous les êtres humains sont doués de raison et de la capacité de distinguer le bien du mal. De plus, selon cette théorie, tous les êtres humains doués de raison sont tenus de faire ce qui est jugé comme bon. En ce sens, les obligations rationnelles se distinguent des obligations connues seulement par la Révélation tels que les rituels religieux, y compris le jeûne, la prière et les exigences en matière d'alimentation.

L’article commence par introduire la méta-éthique ash'arite puis établit brièvement la relation perçue entre la méta-éthique et l'éthique normative, ainsi que le lien existant entre l'éthique, la jurisprudence islamique (ușül alfiqh) et la théologie spéculative ('ilm al-kalām). Dans une première section, elle aborde les présupposés méta-éthiques du Coran, et soutient que l'éthique coranique permet de repenser le fondement méta-éthique des maqāssid, puisqu'elle accepte des valeurs morales objectives et permet une épistémologie morale basée sur la raison. Une deuxième section étudie la controverse sur la justification ultime des jugements moraux dans la pensée arabo-islamique, tandis que la dernière section tente de critiquer les fondements ash'arites de la théorie des maqāṣid en développant des arguments qui tendent à admettre la capacité de la raison humaine à formuler des objectifs supérieurs de la loi islamique ( maqāşid), suggérant par là que cela nécessite un fondement éthique différent, plus proche de la conception mu'tazilite de la morale.

\section{A. Kevin Reinhart}

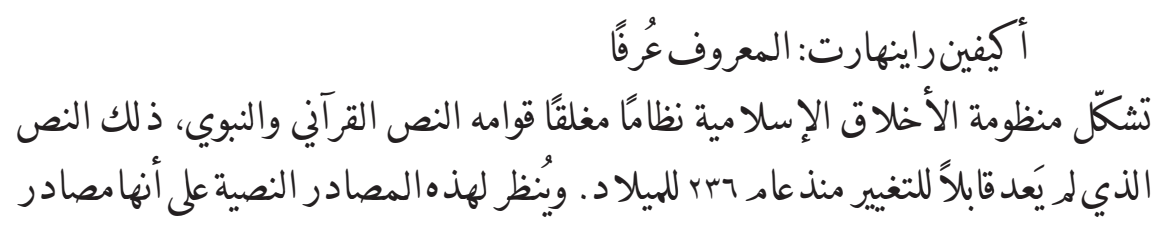


تشريعية تُشئئ الأحكام ومنها تتألف الشريعة، ولكن هذه الدراسة التي يين أيدينا ترى أن هذا

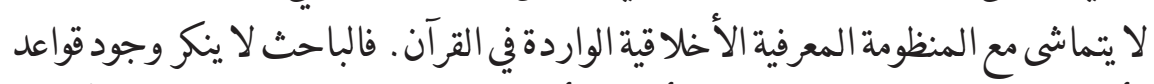

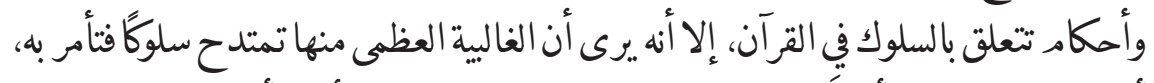

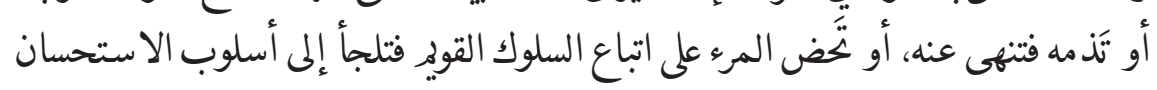

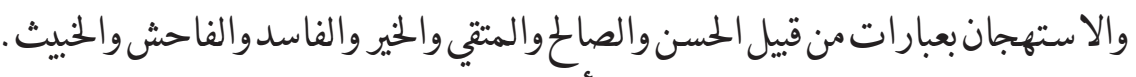

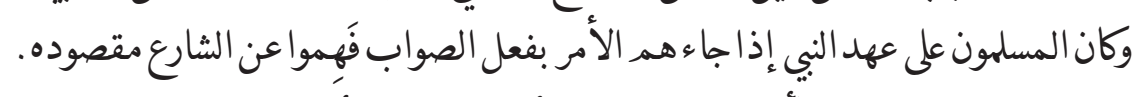

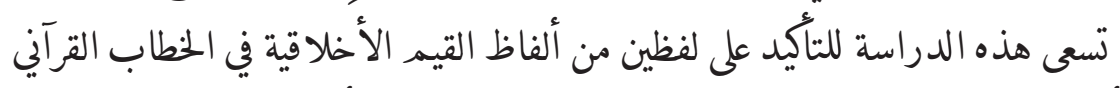

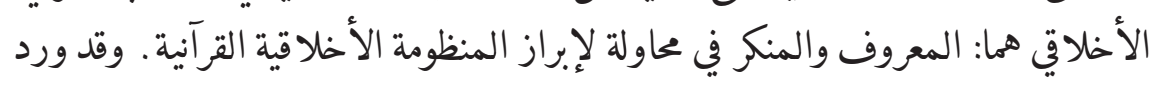

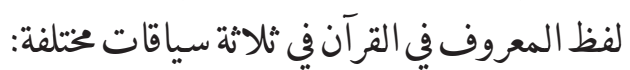

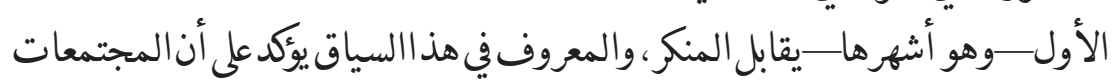

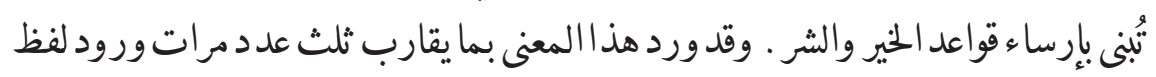
المعروف في القرآن. الثاني هو الأمر بالإخلاص، فتكون نية العمل جلية واضحة. فالإخلاص والاستقامة هي

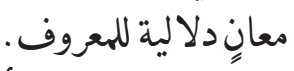

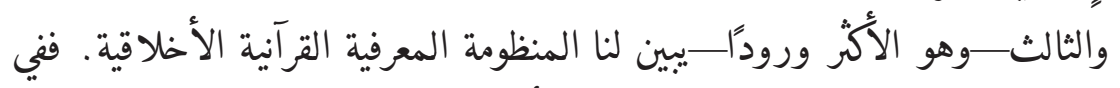

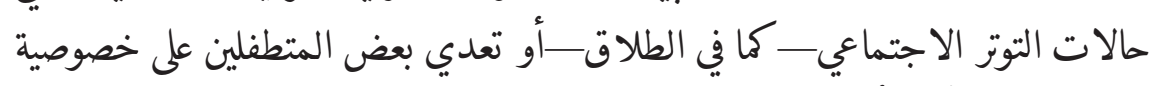

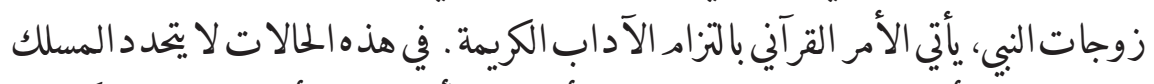

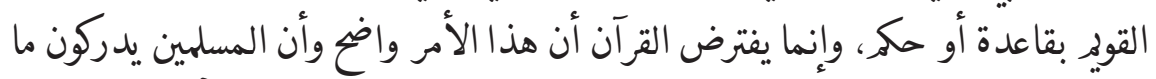

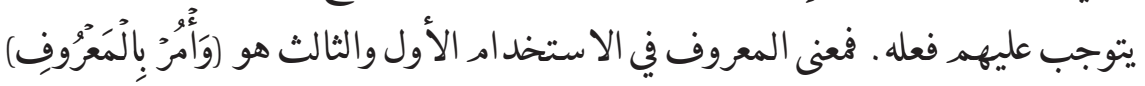

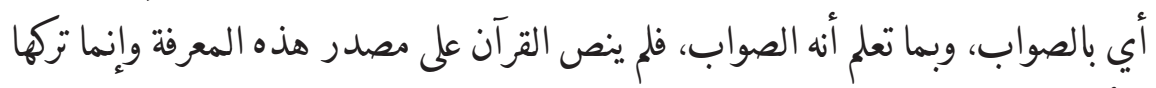

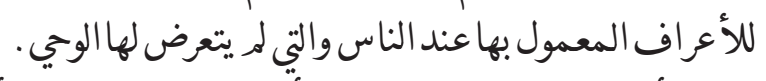

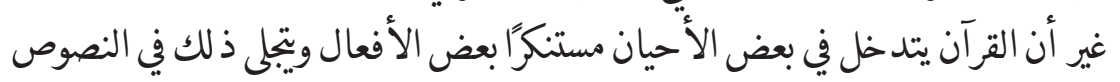

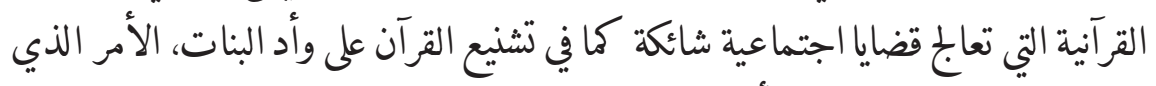

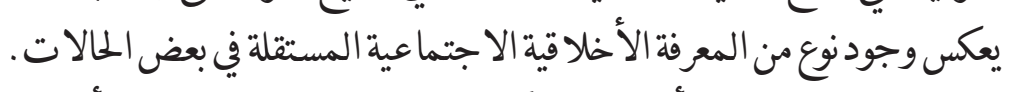

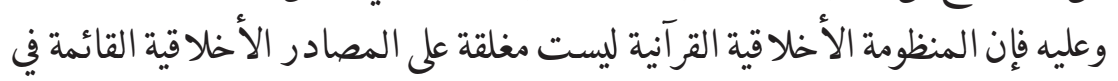

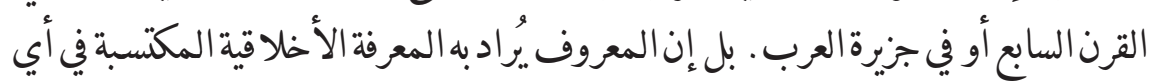

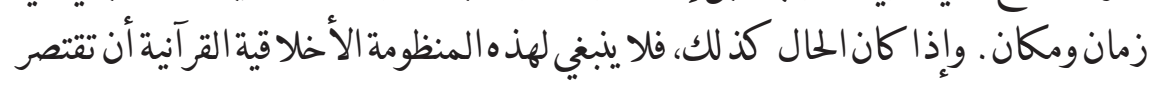




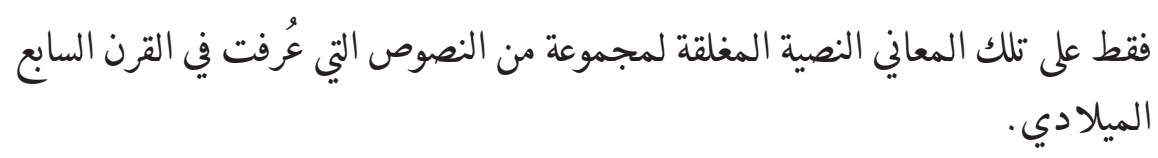

\section{A. Kevin Reinhart, Ce que l'on sait sur la notion de ma' rüf}

Le présent papier de recherche soutient que deux termes revêtant une grande importance au sein du discours éthique coranique, en l'occurrence ma'rüf (littéralement, "ce qui est connu") et le terme qui lui est opposé, munkar (littéralement "ce qui est condamné"), éclairent la morale coranique.

Il existe ainsi trois contextes d'emploi du terme ma'rüf dans le Coran. Le premier, et le plus connu, est celui qui s'oppose à ce qui est "condamné, réprouvé" (al-munkar). Il connote "ce qui est approuvé" et affirme que les sociétés sont fondées sur des normes recommandant le bien et proscrivant le mal. Cet emploi représente moins d'un tiers des occurrences totales du terme ma'rüf dans le texte coranique.

Le second emploi a trait à l'injonction d'agir avec probité. En ce sens, le $m a^{\prime} r u \bar{f}$ signifie que l'intention réelle de l'acte peut être connue à partir de l'acte lui-même. Ici, les termes "sincérité" et "probité" sont sémantiquement liés au ma'rüf.

La plus grande partie des autres emplois faits du terme ma'rüf éclaire toute l'épistémologie éthique coranique. C'est ainsi que dans des situations de tensions sociales, comme celles qui concernent le divorce, ou encore celles se référant à des personnes importunes qui s'immiscent dans la vie privée des épouses du Prophète, le Coran enjoint le "respect des bienséances" . Dans de telles situations, la bonne chose à faire-le bon comportement à adopterne peut être stipulée par une règle précise ; néanmoins, le Coran suppose que les musulmans savent ce qu'ils devraient faire. "Commandez la bonne chose", "faites ce que vous pensez être la bonne chose," telles sont donc les significations de la première et troisième catégorie des emplois du terme márüf. In fine, ne fixant pas une source précise pour cette connaissance, le Coran fait appel à des normes puisées dans des sources autres que celles liées à la Révélation.

En revanche, il est des cas où le Coran affirme explicitement que telle ou telle pratique est malveillante. En attestent les passages coraniques formulant une critique de certaines pratiques sociales-par exemple, la condamnation de l'infanticide-qui mettent en évidence l'hypothèse d'une connaissance socio-éthique indépendante dans d'autres cas. Il s'ensuit que le système éthique coranique n'est pas strictement limité aux sources éthiques antérieures au VII ${ }^{\text {ème }}$ siècle et à l'Arabie. Autrement dit, ce que les musulmans savent est censé se référer à des connaissances éthiques acquises en tout lieu et en tout temps. Si tel est le cas, le système éthique coranique proprement dit ne 
devrait pas reposer sur un corpus textuel fermé composé de textes datant du VII ${ }^{\text {ème }}$ siècle.

\section{Mutaz al-Khatib}

\section{Mutaz al-Khatib, "Ethical Verses": The Question of Ethics among the Exegetes}

The present research addresses the concept of "verses of ethics" as an alternative to the concept of "verses of legal rules," which has been commonly used among Islamic jurists and exegetes. The research poses the concept of ethics as a science and discusses the interference between the ethical and the jurisprudential domains, and the attempts initiated to distinguish between them over the course of history.

The research explains that the exegetes failed to adopt a specific theoretical conception about Qur'anic ethics (or the Qur'an's moral aspect) outside the framework of the Greek philosophical conceptions, which consider ethics as a branch of philosophy or practical wisdom. As a result, the Qur'an did not constitute a referential framework that governed the ethical conceptions or the attempt to explore them.

The author explores the reasoning methods of ancient exegetes who studied the ethical aspect of the Qur'an. He examines in particular the verses that reportedly express the origins of the science of ethics and dwells on verse 199 of Sūrat Al-A'rāf (The Heights) and verse go of Sūrat An-Nahl (The Bee). He concludes that the seven major terms or phrases mentioned in these two verses (justice, the doing of good, all that is shameful, all that runs counter to reason, envy, making due allowance, and doing of what is right) are "universal concepts" per se.

Exegetes usually restricted their interpretation to words and passages, and rarely sought to expand the interpretation horizon in order to capture the major underlying concepts and conceptions. Even those who attributed to these terms general meanings failed to free themselves from their own semantic preoccupations and the particular Qur'anic context in order to establish general ethical conceptions.

Several criticisms were addressed to the exegetes, the jurists and the Sufis on the grounds of marginalizing the Qur'anic reference in the effort of establishing an Islamic science of ethics. The present research concluded that such criticisms were valid. Furthermore, the research found out that the exegetes who studied the Qur'anic verses of ethics relied on the Greek heritage in their interpretation. 
According to the author. this situation is due to the instable theoretical conception of the science of Islamic ethics and its failure to benefit from hermeneutics, as the exegetes contented themselves with initiating a particular method for deducting the rules of law, despite certain limited attempts to end the external influences.

\section{Mutaz al-Khatib, Les «versets de l'éthique ». La question de l'éthique chez les exégètes}

La présente recherche traite le concept de "versets moraux" par opposition à celui des "versets des jugements" qui s'est répandu auprès des jurisconsultes et des exégètes et qui a inspiré des ouvrages en la matière. Ainsi, elle libère le concept de morale en la présentant en tant que science et s'attache à discuter la problématique de l'interférence du moral et du jurisprudentiel, ainsi que les tentatives d'établir des distinctions entre ces deux domaines tout au long de l'histoire.

La recherche souligne également que les exégètes n'ont jamais vraiment nourri une conception théorique particulière autour de la morale coranique ou de l'aspect moral du Coran en dehors du cadre des conceptions philosophiques grecques. Ces conceptions-là, rappelons-le, considèrent la morale comme l'une des branches de la philosophie ou de la sagesse pratique.

La recherche essaie d'élucider les modalités de raisonnement des anciens exégètes qui ont étudié l'aspect moral du Coran et examine les versets dont il est soutenu qu'elles expriment les principes fondateurs de l'éthique. Elle s'attarde en particulier au verset 199 de la Sourate $A l-A^{\prime} r a ̄ f(7)$ et au verset 90 de la Sourate Al-Nahl (16). Elle conclut que les sept mots mentionnés dans ces deux versets (l'équité, la bienfaisance, la turpitude, l'acte répréhensible, la rébellion, le raisonnable et le convenable) renvoient à des "concepts universels". Ces concepts-là sont considérés comme des valeurs morales absolues dont l'interprétation a fait l'objet de controverses parce qu'elles sont précisément absolues et parce qu'il n'est point possible de réduire ou de maîtriser l'absolu.

Les exégètes, les jurisconsultes et les soufis ont été largement critiqués pour avoir marginalisé le rôle de la référence coranique dans l'établissement d'une éthique islamique proprement dite. La présente recherche a étudié en pratique leur travail à travers l'examen des deux versets mentionnées plus haut. Elle a conclu, d'une part, que les critiques qui leur sont adressées sont fondées et que la recherche sur la présence d'une langue morale coranique porteuse de caractéristiques distinctives fait défaut. Elle a également mis en évidence que les exégètes qui se sont préoccupés des versets à caractère moral se sont appuyés sur l'héritage grec dans leur interprétation du sens de ces versets. 
Cette situation est due à deux raisons particulières. D'une part, à l'absence d'une conception théorique de l'éthique. D'autre part, à l'absence d'un emploi de l'herméneutique dans le domaine moral, étant donné que les herméneutes se sont simplement contentés d'établir une méthode particulière pour déduire les règles, sans aller plus loin dans la recherche sur l'éthique.

\section{Abdulrahman Helli}

\section{Abdulrahman Helli, The Concept of Righteousness and the Qur'anic Ethical System: Structure and Context}

The present research paper addresses "righteousness" (birr) as a central ethical concept in the Qur'an, drawing on a methodology that combines linguistic and contextual inquiry. At the linguistic level, the paper examines lexical and historical dimensions. The lexical dimension traces the etymology of the root, as well as its derivations and meanings. As for the historical dimension, it tracks the evolution of the use of the term "righteousness" before the advent of Islam, then in the poems of the pre-Islamic period of Jāhiliyya, and finally in the Qur'anic text itself.

The research highlights the contextual analysis through two distinct dimensions, one historical, the other structural. The historical dimension tracks the evolution in the use of the term righteousness in the Qur'an, according to the chronological order in which the suras were revealed and the contexts in the Makki and the Madani suras. As for the structural dimension, it specifies the meaning of "righteousness" within the Qur'anic text, considered as one single structure, regardless of the diachronic development of the term.

The study further highlights the positive ethical overtone carried by the concept of "righteousness", which suggests an elevation to perfection and denotes two meanings, namely the sincerity of attitude and the nobility of action.

According to the author, "righteousness" is a common denominator of the various religious messages which preceded the advent of Islam. In the Qur'an, the obligations assigned to the faithful are based on "righteousness" which constitutes the source of all obligations. Therefore, the Qur'an transcends the interest that other nations show vis-à-vis the forms and means of obligations, without taking account of their essence and objectives.

The researcher believes that the definitions proposed by all exegetes of "righteousness" as a concept in most Qur'anic contexts lack accuracy and lead to ambiguity and confusion, although exegetes agree that this concept encompasses all actions considered as positive and commendable from religious and ethical perspectives. 
The research concludes by devising a structural and synthetic picture of the concept of "righteousness", which seeks to revive the linguistic methodology (from a lexical and historical point of view) reflecting the textual and historical context within the entire Qur'anic discourse.

This paper takes it that "righteousness" holds a higher rank than the other Qur'anic concepts that are close to it, such as piety, obedience, and honesty in the accomplishment of good deeds.

\section{Abdulrahman Helli, Le concept de droiture et le système moral coranique. Structure et contexte}

Cette étude aborde la question de la droiture (birr) en tant que concept moral central dans le Coran et s'appuie sur une méthodologie qui associe l'examen linguistique à l'examen contextuel du concept. Dans l'examen proprement linguistique, l'étude traite deux dimensions distinctes : la dimension lexicale et la dimension historique. La dimension lexicale remonte à la racine du mot ou à l'étymon et à ses différentes dérivations et significations, dans le but d'en révéler le sens profond. Quant à la dimension historique, elle retrace le développement de l'usage du mot "droiture" avant l'apparition de l'Islam, puis dans les poèmes datant de l'époque préislamique de la jāhiliyya, ainsi que dans le texte coranique en soi.

Quant à l'examen contextuel du concept de droiture, il a été conduit selon deux dimensions distinctes : la dimension historique et la dimension structurelle. L'étude démontre, en fin de compte, que le concept de droiture porte un sens moral positif et désigne l'aspiration à la perfection, tout en dénotant ces deux autres significations nourries par la racine du mot : l'attitude sincère et la grandeur d'action.

L'auteur a soumis à un travail d'induction et d'analyse les citations coraniques autour de la droiture, extraites des versets mekkois et médinois, ainsi que les interprétations présentées par divers exégètes, qu'ils soient anciens ou contemporains, de ce concept. Il considère que la droiture constitue un dénominateur commun entre tous les messages religieux antérieurs à l'Islam. Dans le Coran, les obligations assignées aux fidèles s'appuient sur la droiture qui constitue la source de toutes les obligations et le secret de leur efficacité dans la réalité individuelle et collective. Ainsi, le Coran dépasse l'intérêt porté par les autres nations aux formes et aux modalités des obligations, sans tenir compte de leur essence et de leurs objectifs. L'auteur estime également que les définitions proposées par la plupart des exégètes du concept de droiture manquent de précision.

Cette démarche nécessite la prise en compte des différences existant entre les divers contextes. De même, il convient de tenir compte des facteurs 
déterminants qui sous-tendent les principes de base, les caractéristiques et le statut de la droiture, à l'aune des valeurs religieuses et morales. Tous ces facteurs confirment que la droiture occupe un rang plus élevé que les autres concepts coraniques qui s'en rapprochent, telles que la piété, l'obéissance et l'honnêteté dans l'accomplissement du bien.

\section{Samir Rashwani}

\section{Samir Rashwani, The Ethical Lesson of the Qur'an: Review of some Modern Approaches}

The Islamic ethical heritage has until recently remained scattered in various areas of knowledge, such as jurisprudence (figh), scholastic theology (kaläm), and interpretation (tafsir). Broadly speaking, the Qur'anic ethical vision had to wait until the modern age to fall under a particular theoretical framework.

The study of Muhammad Abdallah Draz (Ethics in the Qur'an, 1947) was a leading reference in the field of Qur'anic studies. It was followed by numerous studies which offered outstanding philosophical and methodological contributions, such as the philosophical study of Daud Rahbar (God of Justice, 1953), the linguistic-philosophical analysis of Toshihiko Izutsu (Ethico-Religious Concepts in the Quran, 1959), as well as other studies by Fadl Al-Rahman, Georges Hourani and many others.

The present study analyzes the methodical and theoretical contribution offered by the works mentioned above. It sheds light on the philosophical thesis of Draz which analyzes the argumentation structure of the Qur'anic text and considers it as a basis for inferring the ethical philosophy of the Scripture of Islam.

The study also addresses Draz's idea of "creative effort", which is considered as one of the bases of the ethical theory, tracing its origins in the thought of Imam Al-Shātibī. Moreover, the study highlights the idea of "double light" as an epistemological basis for the Qur'anic ethical theory. The study further exposes the practical and analytical contribution of Daud Rahbar as it appeared in his thesis on the concept of justice as a regulator of both divine and human ethics. The works of Izutsu remain the most influential of all, thanks to the semantic analysis method that he proposed for studying the Qur'anic text and understanding its ethical discourse. In addition, the study pinpoints the shortcomings and gaps of these works in terms of both methodology and application.

The study also reveals the enthusiasm and the keen interest that some Muslim researchers have shown since the early 20 th century about addressing 
ethics in general, and Qur'anic ethics in particular. The researchers in question are mainly those who lived in or reached out to Western countries and learned about modern philosophical and ethical discourse.

The research works undertaken have yielded several leading philosophical views and analytical methods in addressing the ethical question in the Qur'an. However, this ethical lesson failed to last sustainably or evolve, except maybe through the philosophical theses proposed by Taha Abdurrahmane.

\section{Samir Rashwani, La leçon morale du Coran. Interprétation de certaines approches modernes}

L'héritage islamique moral est resté jusqu'à récemment éparpillé dans diverses branches de la connaissance, telles que la jurisprudence (figh), la théologie scholastique (kalām) et l'exégèse (tafsīr). La consécration théorique ou, plus exactement, la délimitation de la vision morale coranique n'a été entreprise qu'à l'époque moderne. À cet égard, l'étude du Professeur Mohammed Abdallah Draz (La morale du Coran, 1947) a joué un rôle précurseur dans le champ des études coraniques. Cette étude a été suivie par diverses recherches qui ont apporté des contributions philosophiques et méthodologiques pionnières à la question morale dans le Coran. Nous pouvons citer, à titre d'exemple, l'étude philosophique de Daud Rahbar (Dieu de justice, 1953), l'analyse linguisticophilosophique de Toshihiko Izutsu (Les concepts éthico-religieux dans le Coran, 1959), ainsi que les nombreuses études menées par Fadl Al-Rahman, Georges Hourani et bien d'autres encore.

La présente étude se concentre sur l'analyse des contributions méthodologiques et théoriques offertes par les études susmentionnées. Elle mit en lumière la thèse philosophique de Draz qui s'appuie sur l'analyse de la structure argumentative du texte coranique dans le but de définir par déduction la philosophie morale du Coran. L'étude aborde la question de "l'effort créateur," déjà traitée par Draz et considérée comme l'un des fondements de la théorie morale, tout en soulignant que cette question s'est d'abord manifestée dans la pensée de l'Imam Al-Shāțibī. L'étude a également abordé l'idée de la "lumière double" en tant que fondement épistémologique de la théorie morale coranique. D'autre part, l'étude passe en revue la contribution pratique et analytique de Daud Rahbar dans sa thèse sur le concept de justice en tant que régulateur de la morale à la fois divine et humaine. Les travaux d'Izutsu sont ceux qui ont marqué le plus les recherches autour de la morale coranique, grâce à la méthode d'analyse sémantique que cet islamologue a proposée pour étudier le texte coranique et comprendre son discours moral.

D'une manière générale, l'étude révèle l'enthousiasme et le grand intérêt que les chercheurs musulmans ont manifestés à l'égard de la morale 
en général, et de la morale coranique en particulier, depuis le début du xxème siècle. Les chercheurs en question sont surtout ceux qui ont vécu en Occident ou entretenu des relations avec des pays occidentaux et pris connaissance du discours philosophique et moral moderne. Toutefois, cette leçon morale n'a pas réussi à se maintenir durablement ou à se développer, à l'exception peut-être des thèses philosophiques proposées récemment par Taha Abdurrahmane. 
